\title{
Analysis of leading commodities from capture fisheries resources at Bitung Oceanic Fishing Port, North Sulawesi
}

\author{
Indonesian title: \\ Analisis komoditas unggulan dari sumber daya perikanan tangkap di Pelabuhan Perikanan \\ Samudera Bitung, Sulawesi Utara
}

\begin{abstract}
Arianda Kusumaningrum ${ }^{1 *}$, Lawrence L.J. Lumingas ${ }^{1}$, Deiske A. Sumilat ${ }^{2}$, Johnny Budiman $^{2}$, Alfret Luasunaung ${ }^{2}$, Veibe Warouw ${ }^{2}$

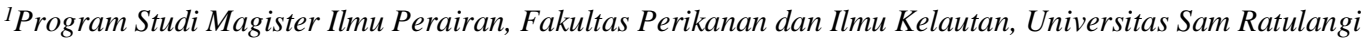
Jl. Kampus Unsrat Bahu, Manado 95115 Sulawesi Utara, Indonesia

${ }^{2}$ Fakultas Perikanan dan Ilmu Kelautan, Universitas Sam Ratulangi, Jl. Kampus Unsrat Bahu, Manado 95115, Sulawesi Utara, Indonesia

*Corresponding author: ari_rimbarum@yahoo.com
\end{abstract}

Received: 19 July 2021 - Revised: 23 August 2021 - Accepted: 2 September 2021

\begin{abstract}
Bitung City is one of the centers of fishery production in Indonesia. Analysis of capture fisheries resources, especially at the Bitung Oceanic Fishing Port (BOFP) as a fish landing center in Bitung city, needs to be done scientifically in order to find out the need for sustainable capture fisheries. The purpose of this research is to analyze the potential of the types of superior commodities that have the opportunity to be developed. Data was collected using survey methods and in-depth interviews with fishermen and local stakeholders. Analysis of the potential of fish resources was carried out using the surplus production method. From the results of the study, it is found that there are 8 (eight) types of leading commodities in BOFP which can be developed with different potentials. They are: 1) Marlin with a sustainable potential of 159 tons, utilization rate of $44 \%$; 2) Tongkol with sustainable potential of 10.485 tons, utilization rate is $58 \%$; 3) Kembung with a sustainable potential of 183 tons utilization rate of 61\%; 4) Big-eye tuna with sustainable potential of 111 tons utilization rate of $69 \%$; 5) Selar with sustainable potential of 450 tons utilization rate of $85 \%$; 6) Yellow Fin Tuna with a sustainable potential of 15.251 tons utilization rate of $86 \%$; 7) Layang with sustainable potential of 7.152 tons utilization rate of $95 \%$, and 8 ) Cakalang.
\end{abstract}

Keywords: fish production; leading commodities; capture fisheries; Bitung fishing port; sustainable fisheries

\section{PENDAHULUAN}

Menurut Sompie (2014), Sulawesi Utara memiliki potensi sumber daya alam laut sebagai penghasil dan pengekspor ikan di mana Kota Bitung merupakan sentra industrinya. Lokasi ini memiliki infrastruktur yang mendukung bongkar-muat dari Kota Bitung ke Pelabuhan Perikanan Samudera (PPS) Bitung.

Secara geografis, posisi Kota Bitung, mulai dari bagian Timur, pesisir pantai Aertembaga hingga ke Tanjung Merah, sampai ke bagian Barat merupakan lokasi strategis untuk dikembangkan menjadi wilayah perkotaan, industri perdagangan, dan jasa, serta pemukiman. Menurut Zulham (2011), Kota Bitung, sebagai sentra perikanan laut dengan pengembangan industri perikanan, lebih tepat diarahkan pada industri pengolahan perikanan laut, sebagai peningkatan nilai tambah potensi ikan ekonomis tinggi, seperti cakalang, tuna, tongkol, dan layang. Di Kota Bitung terdapat kelompok Unit Pengolahan Ikan (UPI) dan kelompok pengolah hasil perikanan tradisional. Industri pengolahan tersebut merupakan usaha potensial yang membutuhkan ikan dengan memanfaatkan ikan yang didaratkan di PPS Bitung.

Perikanan tangkap yang memiliki peranan penting dalam penyediaan pangan, kesempatan kerja, perdagangan, dan kesejahteraan, serta rekreasi bagi sebagian penduduk Indonesia, perlu dikelola dengan berorientasi jangka panjang (Husuna, 2017). 
Secara umum, analisis sumber daya perikanan tangkap perlu dikaji; secara khusus di PPS Bitung, sebagai pusat pendaratan ikan di Kota Bitung. Hal ini dilakukan mengetahui kebutuhan perikanan tangkap yang lestari, berkelanjutan, dan bisa dikembangkan. Penelitian ini bertujuan menganalisis potensi jenis komoditas unggulan yang berpeluang untuk dikembangkan di PPS Bitung.

\section{MATERIAL DAN METODE}

\section{Pengumpulan Data}

Penelitian dilakukan di PPS Bitung, pada bulan Juli sampai dengan Agustus 2020. Data yang digunakan dalam penelitian ini terdiri dari data primer dan data sekunder. Data primer diperoleh dari pengamatan langsung di lapangan dan wawancara dengan nelayan, pengumpul ikan, perusahaan perikanan, pemerintah sebagai pengambil kebijakan, dan pihak terkait lainnya. Data sekunder menggunakan data time-series tahun 2012-2019 yang ada di PPS Bitung.

\section{Analisis Data}

Gulland (1983) menyatakan, jika di suatu daerah perairan terdapat berbagai jenis alat tangkap yang dipakai, maka salah satu alat tersebut dapat dipakai sebagai alat tangkap standar, sedangkan alat tangkap yang lainnya dapat distandarisasikan terhadap alat tangkap tersebut. Alat tangkap yang ditetapkan sebagai alat tangkap standar mempunyai faktor daya tangkap (fishing power indeks/FPI) $=1$ (Tampubolon, 1983). Untuk jenis alat tangkap lainnya, perhitungan nilai FPI dilakukan dengan cara membagi nilai catch per unit effort (CPUE) dengan CPUE alat tangkap standard. Kemudian, nilai FPI tersebut digunakan untuk mencari upaya standard, yaitu dengan mengalikan nilai FPI dengan upaya penangkapan jenis alat tangkap yang dianalisis. Hal tersebut dapat dijelas melalui persamaan berikut ini:

$$
\begin{aligned}
& \text { CPUE }_{\mathrm{s}}: \frac{\mathrm{Cs}}{\mathrm{Fs}} ; \text { CPUE }_{\mathrm{i}}: \frac{\mathrm{Ci}}{\mathrm{Fi}} ; \text { FPIs }: \frac{\text { CPUEs }}{\text { CPUEi }}=1 ; \\
& \text { FPIs }: \frac{\text { CPUEi }}{\text { CPUES }}
\end{aligned}
$$

Untuk alat tangkap lainnya menggunakan persamaan berikut ini:

Standart Effort $=\Sigma$ FPIi x $\Sigma$ E; di mana CPUE: Hasil tangkapan per upaya penangkapan alat tangkap standar; $\mathrm{CPUE}_{\mathrm{i}}$ : Hasil tangkapan per upaya penangkapan alat tangkap $i$; : Upaya dengan alat tangkap $i$; Cs: Jumlah tangkapan jenis alat tangkap standar; $C i$ : Jumlah tangkapan jenis alat tangkap $i$; $F s$ : Jumlah upaya jenis alat tangkap standar; $F_{\mathrm{i}}$ : Jumlah upaya jenis alat tangkap $i$; FPI $I_{s}$ : Faktor daya tangkap jenis alat tangkap standar; $F P I_{i}$ : Faktor daya tangkap jenis alat tangkap $i$.

Salah satu metode pendugaan stok ikan yang biasa adalah adalah metode surplus produksi, yang digunakan dalam perhitungan potensi lestari maksimum (MSY) dan upaya penangkapan optimum dengan cara menganalisis hubungan upaya penangkapan (E) dengan hasil tangkapan per satuan upaya (CPUE).

Data yang digunakan dalam perhitungan adalah data hasil tangkapan dan upaya penangkapan dari PPS Bitung tahun 2012-2019. Dalam analisis data digunakan pendekatan model Schaefer. Berdasarkan parameter model surplus produksi yang diperoleh, kemudian dilakukan penyusunan fungsi produksi. Hubungan hasil tangkapan dengan upaya penangkapan adalah $\mathrm{C}$ : $\mathrm{aE}-\mathrm{bE}^{2}$. Hubungan antara CPUE dengan upaya penangkapan adalah CPUE: abE. Perhitungan upaya penangkapan optimum (Eopt) dilakukan dengan menurunkan persamaan di atas sama dengan 0 , yaitu:

$$
\frac{d C}{d E}: a-2 E ; 0: a-2 b E ; a: 2 b E ; F_{\text {opt }}: a / 2 b
$$

Potensi lestari $(M S Y)$ dihitung sebagai berikut: MSY: $a(a / 2 b)-b\left(a^{2} / 4 b^{2}\right) ; M S Y: a^{2} / 2 b-b a^{2} / 4 b^{2}$; MSY: $2 \mathrm{a}^{2} / 4 \mathrm{~b}-\mathrm{a}^{2} / 4 \mathrm{~b}$; MSY: $\mathrm{a}^{2} / 4 \mathrm{~b}$; di mana $a$ : konstanta, intersep (titik perpotongan garis regresi dengan sumbu $y$ ); $b$ : slope (kemiringan dari garis regresi); $c$ : catch per unit effort; MSY: maximum sustainable yield (potensi lestari).

Perhitungan analisis regresi model Schaefer digunakan untuk mendapatkan nilai besarnya potensi lestari (MSY), upaya optimum (Foptimum), jumlah tangkapan yang diperbolehkan (JTB), dan Tingkat Pemanfaatan suatu jenis komoditas yang kemudian hasilnya disesuaikan dengan studi literatur sesuai pendekatan Bailey et al. (1987) dan FAO (1995), yang telah mengelompokkan status pemanfaatan sumber daya ikan di suatu perairan.

\section{HASIL DAN PEMBAHASAN}

\section{Gambaran Umum Lokasi Penelitian}

Kota Bitung secara geografis terletak di antara $1^{\circ} 23^{\prime} 23^{\prime \prime}-1^{\circ} 35^{\prime} 39^{\prime \prime}$ LU dan $125^{\circ} 1^{\prime} 43^{\prime \prime}-125^{\circ} 18^{\prime} 13^{\prime \prime}$ BT. Pelabuhan Perikanan Samudera (PPS) Bitung terletak di Kelurahan Aertembaga Satu, Kecamatan Aertembaga, Kota Bitung. Wilayah Pengelolaan Perikanan (WPP) PPS Bitung meliputi Laut Maluku (WPP RI 715), Laut Sulawesi (WPP RI 716), dan merupakan pintu gerbang ke Samudera Pasifik (WPP RI 717). 
Kusumaningrum et al.: Analysis of leading commodities from capture fisheries resources at Bitung ...

Tabel 1. Jenis dan jumlah kapal yang berpangkalan di PPS Bitung Tahun 2019

(Statistik PPS Bitung 2019; unpublished data)

\begin{tabular}{|c|c|c|c|c|c|c|c|}
\hline \multirow{2}{*}{ Alat Penangkapan Ikan } & \multicolumn{6}{|c|}{ Gross Tonnage } & \multirow{2}{*}{ Jumlah } \\
\hline & $1-5$ & $6-10$ & $11-30$ & $31-60$ & $61-100$ & $>100$ & \\
\hline Gill Net & 1 & 0 & 0 & 0 & 1 & 5 & 7 \\
\hline Hand Line & 284 & 118 & 225 & 21 & 0 & 0 & 648 \\
\hline Kapal Latih & 0 & 0 & 0 & 1 & 0 & 0 & 1 \\
\hline Kapal Riset & 0 & 0 & 0 & 0 & 0 & 1 & 1 \\
\hline Light Boat & 5 & 23 & 63 & 1 & 0 & 0 & 92 \\
\hline Long Line & 1 & 0 & 13 & 0 & 1 & 0 & 15 \\
\hline Pengangkut Ikan & 0 & 0 & 21 & 6 & 3 & 12 & 42 \\
\hline Penyangga & 0 & 0 & 0 & 1 & 6 & 23 & 30 \\
\hline Pole And Line & 0 & 0 & 1 & 2 & 14 & 0 & 17 \\
\hline Purse Seine & 24 & 26 & 92 & 31 & 36 & 12 & 221 \\
\hline Total & 315 & 167 & 415 & 63 & 61 & 53 & 1.074 \\
\hline
\end{tabular}

Tabel 2. Hasil tangkapan ikan yang didaratkan di PPS Bitung (2012-2019)

(Statistik PPS Bitung, 2019; unpublished data)

\begin{tabular}{|c|c|c|c|c|c|c|c|c|c|c|}
\hline \multirow{2}{*}{ Jenis Ikan } & \multicolumn{9}{|c|}{ Hasil Tangkap (ton) } & \multirow{2}{*}{$(\%)$} \\
\hline & 2012 & 2013 & 2014 & 2015 & 2016 & 2017 & 2018 & 2019 & Total & \\
\hline Cakalang & 11.897 & 46.304 & 39.982 & 18.700 & 14.679 & 13.453 & 13.125 & 13.583 & 171.722 & 48,85 \\
\hline Tuna Sirip Kuning (TSK) & 2.594 & 10.858 & 14.524 & 8.770 & 9.039 & 12.045 & 13.227 & 13.301 & 84.359 & 24,00 \\
\hline Layang & 796 & 5.835 & 5.936 & 7.422 & 5.119 & 5.235 & 6.130 & 6.929 & 43.402 & 12,35 \\
\hline Tongkol & 473 & 4.449 & 6.343 & 9.425 & 10.903 & 2.319 & 2.515 & 2.839 & 39.267 & 11,17 \\
\hline Selar & 1 & 46 & 594 & 441 & 281 & 312 & 562 & 218 & 2.455 & 0,70 \\
\hline Kembung & - & 8 & 114 & 140 & 134 & 134 & 94 & 97 & 720 & 0,20 \\
\hline Tuna Mata Besa & - & - & 78 & 111 & 33 & 70 & 143 & 55 & 490 & 0,14 \\
\hline Marlin & 82 & 29 & 23 & 40 & 164 & 29 & 45 & 73 & 485 & 0,14 \\
\hline HT. Lainnya & 324 & 2.250 & 1.309 & 646 & 1.182 & 848 & 1.362 & 742 & 8.664 & 2,46 \\
\hline Total & 16.167 & 69.779 & 68.903 & 45.695 & 41.534 & 34.445 & 37.203 & 37.837 & 351.564 & 100 \\
\hline
\end{tabular}

\section{Perikanan Tangkap}

Kapal perikanan yang berpangkalan di PPS Bitung memiliki ukuran yang bervariasi, dari yang berukuran <5GT, 5-10 GT, 11-30 GT, dan >30 GT. Pada tahun 2019, alat tangkap dominan di PPS Bitung secara berurutan dari yang paling banyak jumlahnya adalah handline, purse-seine, pole and line (huhate), longline dan gillnet (Tabel 1).

\section{Jenis Komoditas Perikanan Unggulan Di Bitung}

Hasil tangkapan ikan yang didaratkan di PPS Bitung beragam jenisnya. Fish target tersebut disesuaikan dengan penggunaan jenis alat tangkap oleh nelayan. Berdasarkan hasil pengamatan, hasil tangkapan ikan yang didaratkan di PPS Bitung (tahun 2012-2019) beragam jenisnya (Tabel 2). Dari ragamnya hasil tangkapan ikan tersebut, maka dipilih beberapa jenis ikan yang menjadi komoditas unggulan di mana komoditas tersebut selalu ada di tiap tahunnya dan menjadi fish target alat tangkap yang dioperasionalkan oleh nelayan.

Dari persentase jumlah hasil tangkapan ikan yang didaratkan di PPS Bitung (tahun 2012-2019) dapat dilihat, bahwa komoditas unggulan PPS Bitung adalah cakalang, tuna sirip kuning (TSK), layang, tongkol, selar, kembung, tuna mata besar (TMB), dan marlin.

\section{Potensi Komoditas Unggulan untuk dikembangkan Di PPS Bitung \\ - Cakalang}

Hasil perhitungan CPUE dari masing-masing alat tangkap penangkap Cakalang (gillnet, huhate, dan purse-seine) berbeda (Tabel 3). Alat tangkap purse-seine memiliki nilai CPUE tertinggi (Tabel 3). CPUE standar ikan cakalang tahun 2012-2019 sangat bergantung kepada produksi total dan standard effort (Tabel 4).

Analisis fungsi produksi dilakukan untuk mengetahui hubungan hasil tangkapan dengan upaya penangkapan ikan. Gambar 1 memperlihatkan fungsi produksi cakalang. Nampak, hubungan effort dan CPUE cakalang tahun 2012-2019 didapatkan persamaan linier $\mathrm{y}=0,0029 \mathrm{x}+11,917$ dengan $\mathrm{R}^{2}=$ 0,0529 . Dari hasil perhitungan dengan menggunakan analisis regresi diperoleh nilai koefisien $(b)$ positif, 
Aquatic Science \& Management, Vol. 9, No. 2 (October 2021)

Tabel 3. CPUE tiap alat tangkap ikan cakalang di PPS Bitung

\begin{tabular}{cccc}
\hline Tahun & Gillnet & $\begin{array}{c}\text { Alat Tangkap } \\
\text { Huhate }\end{array}$ & Purse Seine \\
\hline 2012 & - & 12.304 & 21.928 \\
2013 & 25.000 & 14.258 & 16.481 \\
2014 & 20.000 & 15.722 & 18.062 \\
2015 & - & 13.236 & 12.223 \\
2016 & - & 9.468 & 11.474 \\
2017 & - & 9.762 & 9.155 \\
2018 & - & 12.215 & 8.592 \\
2019 & - & 8.525 & 12.251 \\
Jumlah & 45.000 & 95.490 & 110.166 \\
Rata-rata & 22.500 & 11.936 & 13.771 \\
\hline
\end{tabular}

Tabel 4. Hasil perhitungan produksi total, standard effort, dan CPUE standar ikan cakalang

\begin{tabular}{cccc}
\hline Tahun & $\begin{array}{c}\text { Produksi Total } \\
(\mathrm{kg})\end{array}$ & $\begin{array}{c}\text { Standard Effort } \\
(\text { trip })\end{array}$ & $\begin{array}{c}\text { CPUE Standar } \\
(\mathrm{kg} / \text { trip })\end{array}$ \\
\hline 2012 & 11.896 .624 & 543 & 21.928 \\
2013 & 46.226 .319 & 1.850 & 24.992 \\
2014 & 39.917 .679 & 1.996 & 20.000 \\
2015 & 18.652 .837 & 1.409 & 13.236 \\
2016 & 14.674 .805 & 1.281 & 11.456 \\
2017 & 13.435 .359 & 1.376 & 9.762 \\
2018 & 13.106 .391 & 1.073 & 12.215 \\
2019 & 13.581 .339 & 1.109 & 12.251 \\
\hline
\end{tabular}

maka perhitungan potensi dan upaya penangkapan optimum tidak perlu dilanjutkan, karena hal ini mengindikasikan bahwa penambahan upaya penangkapan masih memungkinkan untuk meningkatkan hasil tangkapan (Simbolon et al., 2011)

Berdasarkan penelitian yang dilakukan Taib et al. (2018), sesuai tangkapan yang didaratkan di PPS Bitung (tahun 2010-2015), musim puncak penangkapan Cakalang berada pada bulan April, Mei, Juni, Agustus, dan Oktober; musim sedang

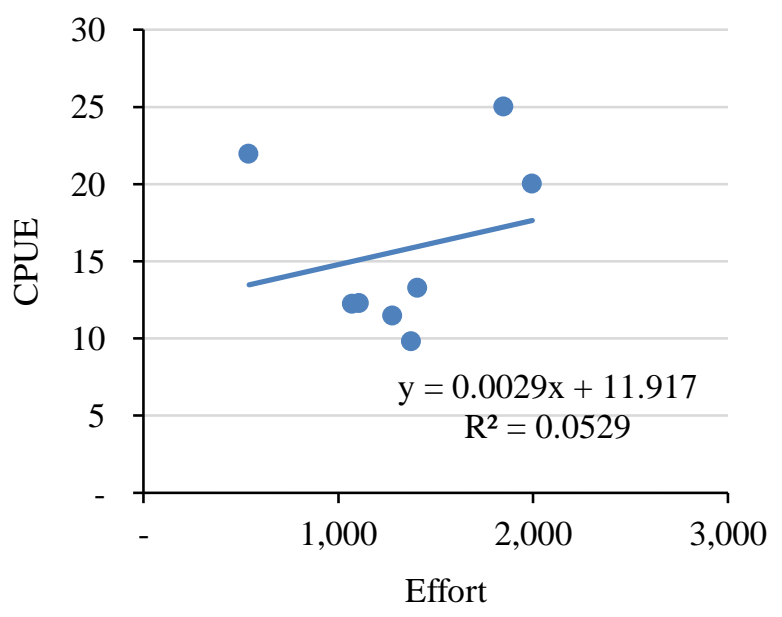

Gambar 1. Grafik fungsi produksi ikan cakalang berada pada bulan Maret, Juli, dan September; dan tidak ada musim terjadi pada bulan Januari-Februari dan November-Desember.

\section{- Tuna Sirip Kuning (TSK)}

Menurut Nakamura (1969), ikan tuna biasa dalam schooling saat mencari makan, jumlah schooling biasa terdiri dari beberapa ekor maupun dalam jumlah banyak. Daerah penyebaran ikan tuna merupakan perairan yang subur di lautan bebas, tempat terjadinya upwelling. Karena habitatnya di perairan dalam, maka disebut sebagai perikanan laut dalam (Soemarto, 1958). Di Laut Maluku, tuna biasa ditangkap dengan handline dengan teknik pengoperasian menggunakan umpan alami kantong hambur (ulami kambur) atau umpan alami berpemberat batu dan tinta cumi (Karyanto et al., 2015). Menurut Darondo et al., 2015, komposisi hasil tangkapan ikan tuna sirip kuning (TSK) yang tertangkap lebih banyak dibandingkan dengan jenis tuna mata besar (TMB).

Dengan menggunakan sistem perhitungan yang sama dengan ikan cakalang, nilai CPUE pada setiap alat tangkap penangkap TSK (gillnet, handline, huhate, purse-seine dan longline) berbeda (Tabel 5). Alat tangkap gillnet memiliki nilai CPUE tertinggi (Tabel 5). Penangkapan TSK yang memiliki nilai produktivitas terbesar adalah gillnet. Tetapi, 
Kusumaningrum et al.: Analysis of leading commodities from capture fisheries resources at Bitung ...

Tabel 5. CPUE tiap alat tangkap tuna sirip kuning (TSK) di PPS Bitung

\begin{tabular}{crrrrr}
\hline \multirow{2}{*}{ Tahun } & \multicolumn{3}{c}{ Alat Tangkap } & & Longline \\
& \multicolumn{1}{c}{ Gillnet } & Handline & Huhate & Purse Seine & \multicolumn{2}{c}{ Long } \\
2012 & - & 604 & 5.575 & 7.239 & 5.078 \\
2013 & 25.667 & 603 & 6.262 & 5.340 & 7.529 \\
2014 & 25.580 & 630 & 8.266 & 8.037 & 5.806 \\
2015 & 18.000 & 491 & 6.063 & 6.308 & 1.977 \\
2016 & 3.748 & 770 & 4.131 & 6.260 & 1.806 \\
2017 & 6.500 & 938 & 7.985 & 6.937 & 1.808 \\
2018 & 4.551 & 1.396 & 8.828 & 4.928 & 1.932 \\
2019 & 5.227 & 1.359 & 4.977 & 4.777 & 1.989 \\
Jumlah & 89.272 & 6.791 & 52.087 & 49.826 & 27.925 \\
Rata-rata & 12.753 & 849 & 6.511 & 6.228 & 3.491 \\
\hline
\end{tabular}

Tabel 6. Hasil perhitungan produksi total, standard effort, dan CPUE standar ikan tuna sirip kuning (TSK)

\begin{tabular}{cccc}
\hline Tahun & $\begin{array}{c}\text { Produksi Total } \\
(\mathrm{kg})\end{array}$ & $\begin{array}{c}\text { Standard Effort } \\
(\text { trip })\end{array}$ & $\begin{array}{c}\text { CPUE Standar } \\
(\mathrm{kg} / \text { trip })\end{array}$ \\
\hline 2012 & 2.593 .717 & 358 & 7.239 \\
2013 & 10.857 .535 & 423 & 25.668 \\
2014 & 14.523 .813 & 568 & 25.577 \\
2015 & 8.770 .290 & 487 & 18.001 \\
2016 & 9.039 .292 & 1.444 & 6.259 \\
2017 & 12.027 .387 & 1.506 & 7.986 \\
2018 & 13.227 .270 & 1.498 & 8.828 \\
2019 & 13.304 .838 & 2.546 & 5.226 \\
\hline
\end{tabular}

alat tangkap gillnet tidak bisa menjadi alat tangkap standar, karena memiliki nilai FPI berbeda-beda tiap tahun. Standard effort dari TSK cenderung meningkat di tiap tahunnya (Tabel 6).

Dari hasil perhitungan, jumlah MSY TSK adalah sebesar 15.251 ton dengan upaya maksimum (Foptimum) sebesar 1.430 (Gambar 2). Sedangkan, rerata jumlah tangkapan tahun 2012-2019 adalah 10.543 ton per tahun sehingga pemanfaatannya masih bisa diteruskan.

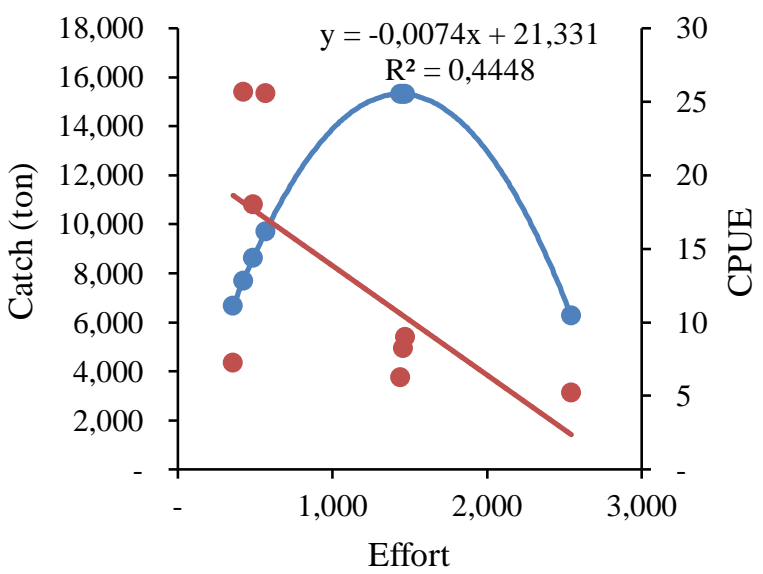

Gambar 2. Grafik nilai MSY ikan tuna sirip kuning (TSK)
Tingkat Pemanfaatan TSK adalah $86 \%$ (fully exploited), yang menyatakan stok sumber daya ikan sudah tereksploitasi mendekati nilai MSY. Dalam keadaan ini, peningkatan jumlah upaya penangkapan sangat tidak dianjurkan, walaupun hasil tangkapan masih dapat meningkat. Peningkatan upaya penangkapan akan mengganggu kelestarian sumber daya ikan dan hasil tangkapan per unit upaya pasti menurun.

\section{- Layang}

Ikan layang (Decapterus) termasuk komponen perikanan pelagis penting di Indonesia. Di perairan Indonesia, terdapat 5 tenis yang umum dijumpai, yaitu D. lajang, D. russelli, D. macrosoma, $D$. kurroides, dan D. maruadsi. Kelima jenis ini terdapat pula di perairan Maluku (Weber and Beaufort, 1931).

Nilai CPUE purse seine untuk menangkap layang mengalami penurunan (Tabel 7); demikian pula halnya dengan ikan kembung. Penurunan CPUE merupakan indikasi terjadinya penurunan kelimpahan stok sumber daya ikan. Apabila keadaan penurunan terus-menerus terjadi, maka dapat memicu growth overfishing dan mengancam keberlanjutan sumber daya ikan layang (Puansalaing et al., 2021).

Jumlah tangkapan maksimal (MSY) layang adalah sebesar 7.152 ton dengan upaya maksimum 
Aquatic Science \& Management, Vol. 9, No. 2 (October 2021)

Tabel 7. CPUE purse seine sebagai penangkap ikan layang di PPS Bitung

\begin{tabular}{cccc}
\hline Tahun & $\begin{array}{c}\text { Produksi Total } \\
(\mathrm{kg})\end{array}$ & $\begin{array}{c}\text { Standard Effort } \\
\text { (trip) }\end{array}$ & $\begin{array}{c}\text { CPUE } \\
(\mathrm{kg} / \text { trip })\end{array}$ \\
\hline 2012 & 794.563 & 197 & 4.033 \\
2013 & 5.834 .299 & 2.037 & 2.864 \\
2014 & 5.926 .999 & 2.444 & 2.425 \\
2015 & 7.420 .692 & 2.082 & 3.564 \\
2016 & 5.115 .352 & 2.015 & 2.539 \\
2017 & 5.210 .266 & 2.698 & 1.931 \\
2018 & 6.109 .457 & 3.950 & 1.547 \\
2019 & 6.918 .164 & 4.301 & 1.609 \\
\hline
\end{tabular}

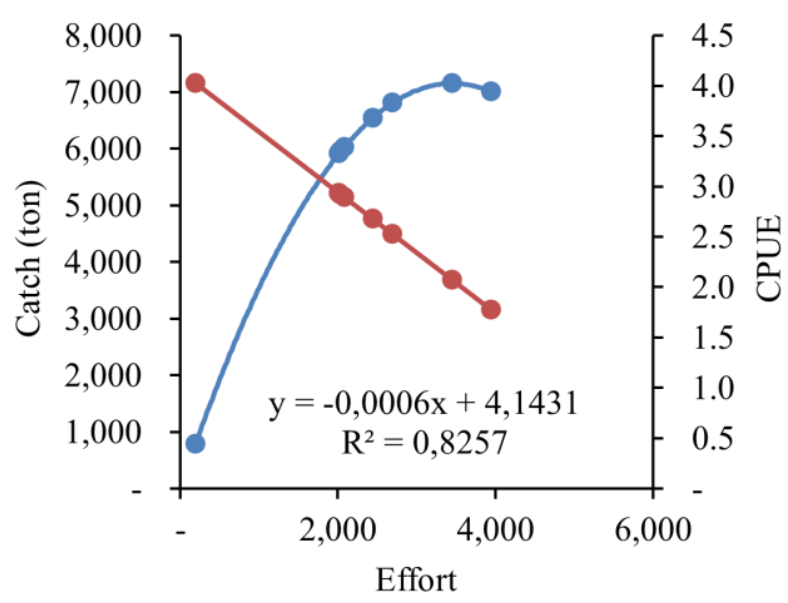

Gambar 3. Grafik nilai MSY ikan Layang

(Foptimum) sebesar 3.453 (Gambar 3). Sedangkan rerata jumlah tangkapan tahun 2012-2019 adalah sebesar 5.416 ton per tahun sehingga pemanfaatannya masih bisa diteruskan.

Tingkat Pemanfaatan layang adalah sebesar 95\% (fully exploited), yang berarti stok sumber daya ikan sudah tereksploitasi mendekati nilai MSY. Di sini, peningkatan jumlah upaya penangkapan sangat tidak dianjurkan, walaupun hasil tangkapan masih dapat meningkat. Peningkatan upaya penangkapan akan mengganggu kelestarian sumber daya ikan, dan hasil tangkapan per unit upaya pasti menurun.

\section{- Tongkol}

Umumnya, ikan tongkol (Euthynnus spp.) hidup hampir di dasar laut. Ikan ini bersifat epipelagis, berenang membentuk schooling, dan umumnya hidup pada kisaran suhu $21,60-30,50{ }^{\circ} \mathrm{C}$. Golongan jenis ini merupakan ikan pemakan daging seperti ikan pelagis kecil (Girsang, 2008). Di Sulawesi utara, ikan tongkol biasa tertangkap dengan menggunakan alat tangkap purse seine dan huhate.

Berdasarkan perhitungan nilai CPUE dari ke tiga alat tangkap penangkap ikan tongkol (gillnet, huhate, dan purse seine), alat tangkap gillnet
Tabel 8. CPUE tiap alat tangkap penangkap ikan tongkol di PPS Bitung

\begin{tabular}{|c|c|c|c|}
\hline \multirow{2}{*}{ Tahun } & \multicolumn{3}{|c|}{ Alat Tangkap } \\
\hline & Gillnet & Huhate & Purse Seine \\
\hline 2012 & - & - & 3.422 \\
\hline 2013 & 8.000 & 3.492 & 2.562 \\
\hline 2014 & 34.472 & 2.806 & 2.367 \\
\hline 2015 & 10.683 & 1.233 & 4.249 \\
\hline 2016 & 12.700 & 3.638 & 2.898 \\
\hline 2017 & 10.500 & 3.740 & 1.949 \\
\hline 2018 & 7.267 & 1.118 & 2.283 \\
\hline 2019 & 13.210 & 520 & 3.175 \\
\hline Jumlah & 96.832 & 16.547 & 22.905 \\
\hline Rata-rata & 13.833 & 2.364 & 2.863 \\
\hline
\end{tabular}

Tabel 9. Hasil perhitungan produksi total, standard effort, dan CPUE standar ikan tongkol

\begin{tabular}{cccc}
\hline Tahun & $\begin{array}{c}\text { Produksi Total } \\
(\mathrm{kg})\end{array}$ & $\begin{array}{c}\text { Standard } \\
\text { Effort } \\
\text { (trip) }\end{array}$ & $\begin{array}{c}\text { CPUE } \\
\text { Standar } \\
\text { (kg/ trip) }\end{array}$ \\
\hline 2012 & 472.246 & 138 & 3.422 \\
2013 & 4.423 .479 & 553 & 8.000 \\
2014 & 6.342 .858 & 184 & 34.479 \\
2015 & 9.420 .931 & 882 & 10.683 \\
2016 & 10.857 .938 & 855 & 12.694 \\
2017 & 2.297 .141 & 219 & 10.501 \\
2018 & 2.502 .659 & 344 & 7.268 \\
2019 & 2.825 .255 & 214 & 13.208 \\
\hline
\end{tabular}

memiliki nilai CPUE tertinggi (Tabel 8). Nilai produktivitas terbesar adalah gillnet (Tabel 8); tetapi, alat tangkap gillnet tidak bisa menjadi alat tangkap standar, karena memiliki nilai FPI yang berbeda tiap tahunnya. CPUE standar ikan tongkol sangat bergantung kepada produksi total dan standard effort (Tabel 9).

Jumlah tangkapan maksimal (MSY) adalah sebesar 10.485 ton dengan upaya maksimum (Foptimum) sebesar 1.425 (Gambar 4). Sedangkan rerata jumlah tangkapan tahun 2012-2019 sebesar 4.893 ton per tahun sehingga pemanfaatannya masih bisa diteruskan.

Tingkat Pemanfaatan tongkol adalah sebesar $58 \%$ (moderately exploited), yang menyatakan stok sumber daya ikan sudah terekploitasi setengah dari MSY. Pada kondisi ini, peningkatan jumlah upaya penangkapan masih dianjurkan tanpa mengganggu kelestarian sumber daya ikan; tetapi, hasil tangkapan per unit upaya mungkin mulai menurun.

\section{- Selar}

Ikan selar mata besar (oci) dan selar mata kecil (tude) sebagai hasil tangkapan ikan pelagis kecil yang tertangkap di perairan sekitar Bitung, memiliki 
Kusumaningrum et al.: Analysis of leading commodities from capture fisheries resources at Bitung ...

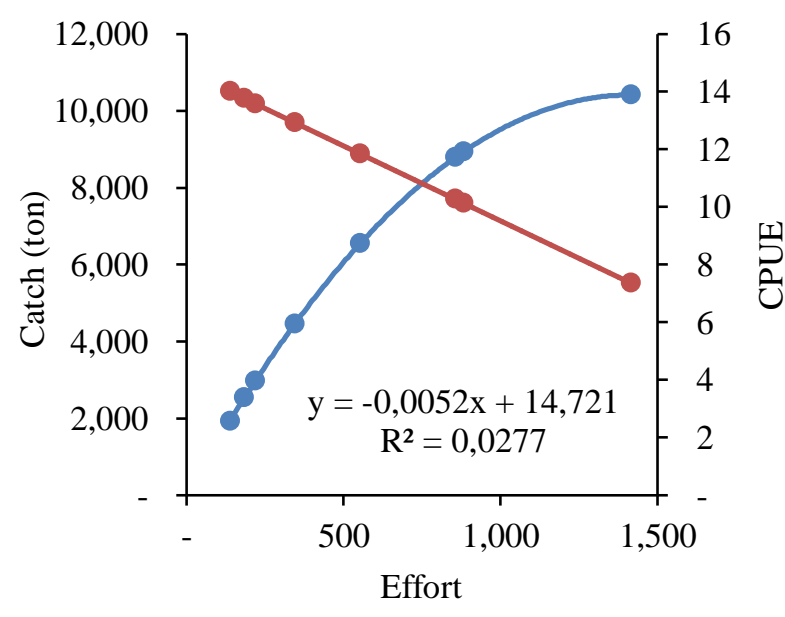

Gambar 4. Grafik nilai MSY ikan tongkol

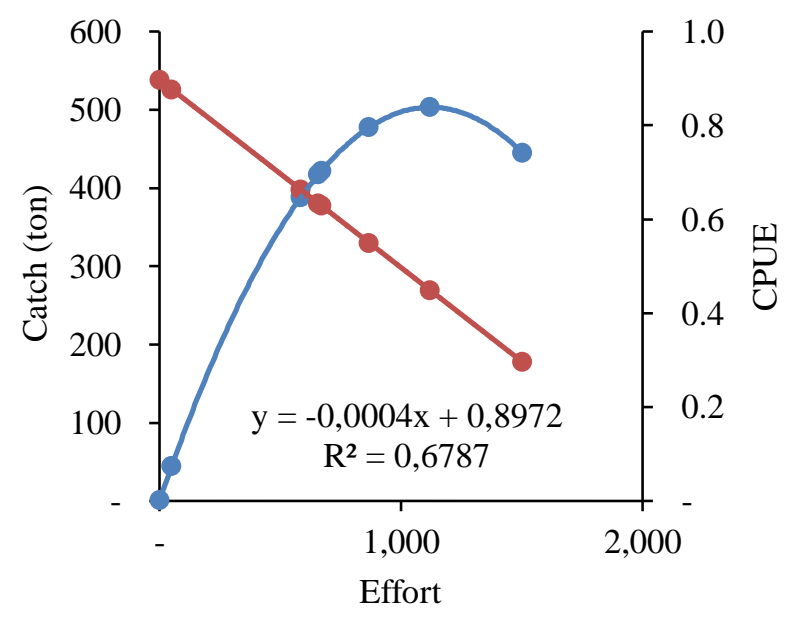

Gambar 5. Grafik nilai MSY ikan selar

perbedaan secara morfologi dan morfometrik. Tetapi, berdasarkan konfirmasi genetik, kedua jenis ikan ini merupakan spesies yang sama 99,83\% (Santoso, 2017).

Nilai CPUE purse seine untuk menangkap selar mengalami penurunan di tiap tahunnya (Tabel 10); demikian pula ikan kembung dan layang. Jumlah tangkapan maksimal (MSY) ikan selar adalah sebesar 450 ton dengan upaya maksimum (Foptimum) sebesar 1.003 (Gambar 5). Rerata jumlah tangkapan tahun 2012-2019 adalah sebesar 306 ton per tahun sehingga pemanfaatannya masih bisa diteruskan.

Tingkat Pemanfaatan selar adalah sebesar $85 \%$ (fully exploited), yang menyatakan stok sumber daya ikan sudah tereksploitasi mendekati nilai MSY. Dengan demikian, peningkatan jumlah upaya penangkapan sangat tidak dianjurkan, walaupun hasil tangkapan masih dapat meningkat. Peningkatan upaya penangkapan akan mengganggu kelestarian sumber daya ikan, dan hasil tangkapan per unit upaya pasti menurun.
Tabel 10. CPUE purse seine sebagai penangkap ikan selar di PPS Bitung

\begin{tabular}{cccc}
\hline Tahun & $\begin{array}{c}\text { Produksi Total } \\
(\mathrm{kg})\end{array}$ & $\begin{array}{c}\text { Standard Effort } \\
\text { (trip) }\end{array}$ & $\begin{array}{c}\text { CPUE } \\
\text { (kg/ trip) }\end{array}$ \\
\hline 2012 & 1.000 & 1 & 1.000 \\
2013 & 46.335 & 51 & 909 \\
2014 & 593.275 & 869 & 683 \\
2015 & 439.737 & 671 & 655 \\
2016 & 278.915 & 585 & 477 \\
2017 & 311.603 & 658 & 474 \\
2018 & 558.469 & 1.502 & 372 \\
2019 & 215.987 & 1.027 & 210 \\
\hline
\end{tabular}

Tabel 11. CPUE purse seine sebagai penangkap ikan kembung di PPS Bitung

\begin{tabular}{cccc}
\hline Tahun & $\begin{array}{c}\text { Produksi Total } \\
(\mathrm{kg})\end{array}$ & $\begin{array}{c}\text { Standard Effort } \\
\text { (trip) }\end{array}$ & $\begin{array}{c}\text { CPUE } \\
(\mathrm{kg} / \text { trip })\end{array}$ \\
\hline 2012 & - & - & - \\
2013 & 7.646 & 3 & 2.549 \\
2014 & 113.635 & 265 & 429 \\
2015 & 139.720 & 266 & 525 \\
2016 & 133.125 & 249 & 535 \\
2017 & 52.710 & 144 & 366 \\
2018 & 79.841 & 341 & 234 \\
2019 & 95.840 & 540 & 177 \\
\hline
\end{tabular}

\section{- Kembung}

Ikan kembung terdiri dari 2 spesies, yaitu ikan kembung lelaki atau banyar (Rastrelliger kanagurta) dan kembung perempuan ( $R$. brachysoma). Alat tangkap purse seine adalah alat tangkap yang cocok digunakan untuk menangkap ikan jenis ini, sama halnya dengan ikan pelagis kecil lainnya, seperti ikan tongkol (Auxis sp.), ikan layang (Decapterus sp.), dan ikan selar (Selaroides sp.).

Berdasarkan perhitungan, nilai CPUE untuk ikan kembung relatif menurun setiap tahun (Tabel 11). Salah satu penyebabnya, karena semakin bertambahnya armada penangkapan ikan kembung sehingga hasil yang diperoleh tidak banyak.

Dari hasil analisis, jumlah MSY adalah sebesar 183 ton dengan upaya maksimum (Foptimum) sebesar 220 (Gambar 6). Sedangkan rerata jumlah tangkapan dari tahun 2013-2019 adalah sebesar 89 ton per tahun sehingga pemanfaatannya masih bisa diteruskan.

Tingkat Pemanfaatan kembung adalah 61\% (moderately exploited) yang berarti stok sumber daya ikan sudah tereksploitasi mendekati nilai MSY. Peningkatan jumlah upaya penangkapan sangat tidak dianjurkan, walaupun hasil tangkapan masih dapat meningkat. Peningkatan upaya penangkapan akan mengganggu kelestarian sumber daya ikan, dan hasil tangkapan per unit upaya pasti menurun. 


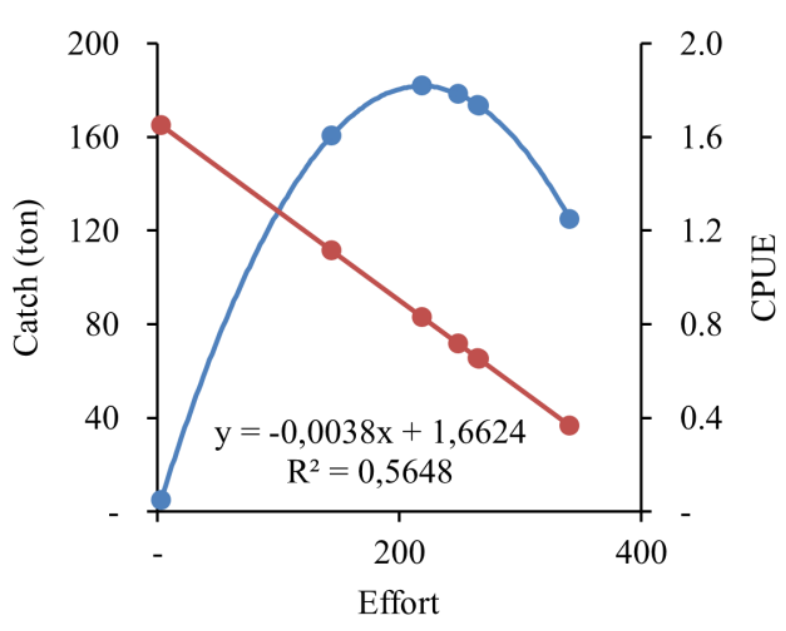

Gambar 6. Grafik nilai MSY ikan kembung

Tabel 12. CPUE tiap alat tangkap tuna mata besar (TMB) di PPS Bitung

\begin{tabular}{ccccc}
\hline \multirow{2}{*}{ Tahun } & \multicolumn{4}{c}{ Alat Tangkap } \\
& Handline & Huhate & Purse Seine & Longline \\
\hline 2012 & - & - & - & - \\
2013 & - & - & - & - \\
2014 & 420 & - & 5.538 & 673 \\
2015 & 444 & 7.045 & 5.161 & 250 \\
2016 & 599 & - & 1.471 & 127 \\
2017 & 1.621 & - & 2.430 & - \\
2018 & 1.036 & 8.000 & 3.034 & 724 \\
2019 & 549 & - & 1.130 & 975 \\
Jumlah & 4.669 & 15.045 & 18.764 & 2.749 \\
Rata-rata & 778 & 5.015 & 3.127 & 550 \\
\hline
\end{tabular}

\section{- Tuna Mata Besar (TMB)}

Perikanan longline sering diartikan sebagai perikanan tuna longline karena tujuan utama penangkapan dengan alat ini adalah ikan dari jenis tuna walaupun dalam kenyataannya tertangkap juga ikan-ikan yang lain.

Berdasarkan perhitungan nilai CPUE ke empat alat tangkap penangkap TMB (handline, huhate, purse seine dan longline), alat tangkap purse seine memiliki nilai CPUE tertinggi (Tabel 12). Penangkapan TMB yang memiliki nilai produktivitas terbesar adalah purse seine. Tetapi, alat tangkap purse seine tidak bisa menjadi alat tangkap standar dikarenakan memiliki nilai FPI yang berbeda-beda tiap tahun. Standard effort dari TMB cenderung meningkat di tiap tahunnya (Tabel 13).

Jumlah MSY TMB adalah sebesar 111 ton dengan upaya maksimum (Foptimum) sebesar 28 (Gambar 7). Rerata jumlah tangkapan pada tahun 2012-2019 adalah sebesar 61 ton per tahun sehingga pemanfaatannya masih bisa diteruskan.

Tingkat Pemanfaatan TMB adalah 69\% (moderately exploited) yang menyatakan stok

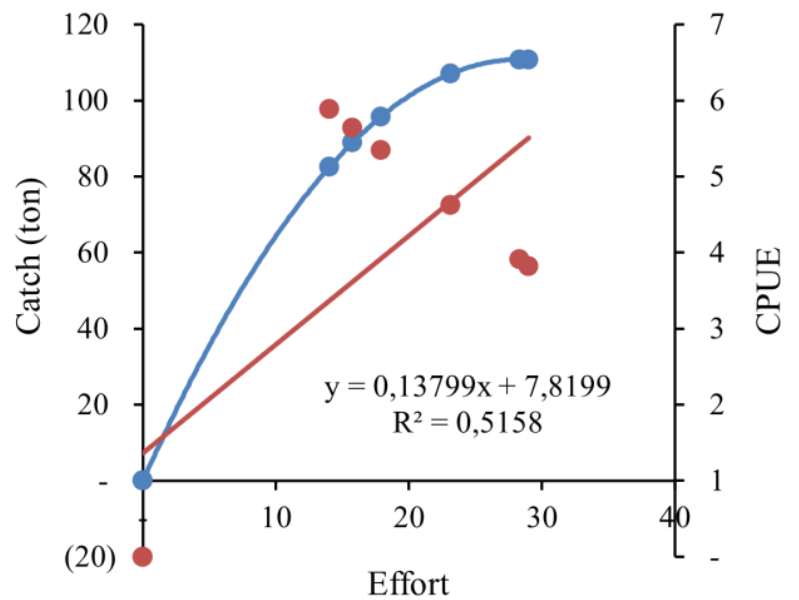

Gambar 7. Grafik nilai MSY ikan tuna mata besar

Tabel 13. Hasil perhitungan produksi total, standard effort, dan CPUE standar ikan tuna mata besar (TMB)

\begin{tabular}{rrrr}
\hline Tahun & $\begin{array}{c}\text { Produksi Total Standard Effort } \\
\text { (kg) }\end{array}$ & $\begin{array}{c}\text { CPUE Standar } \\
\text { (trip) }\end{array}$ & \multicolumn{1}{c}{ (kg/trip) } \\
\hline 2012 & - & - & - \\
2013 & - & - & - \\
2014 & 77.599 & 14 & 5.538 \\
2015 & 111.081 & 16 & 7.045 \\
2016 & 32.986 & 23 & 1.425 \\
2017 & 70.473 & 29 & 2.430 \\
2018 & 143.096 & 18 & 7.999 \\
2019 & 54.639 & 56 & 975 \\
\hline
\end{tabular}

sumber daya ikan sudah tereksploitasi mendekati nilai MSY. Peningkatan jumlah upaya penangkapan sangat tidak dianjurkan, walaupun hasil tangkapan masih dapat meningkat. Peningkatan upaya penangkapan akan mengganggu kelestarian sumber daya ikan dan hasil tangkapan per unit upaya pasti menurun.

\section{- Marlin}

Dengan menggunakan sistem perhitungan yang sama dengan ikan cakalang, nilai CPUE dari ke empat alat tangkap penangkap marlin yang digunakan (gillnet, handline, purse seine dan longline), gillnet memiliki nilai CPUE tertinggi (Tabel 14). Penangkapan ikan marlin yang memiliki nilai produktivitas terbesar adalah gillnet. Tetapi, alat tangkap gillnet tidak bisa menjadi alat tangkap standar, karena memiliki nilai FPI yang berbedabeda setiap tahun. CPUE standar ikan marlin sangat bergantung kepada produksi total dan standard effort (Tabel 15).

Jumlah MSY ikan marlin adalah sebesar 159 ton dengan upaya maksimum (Foptimum) sebesar 70 
Kusumaningrum et al.: Analysis of leading commodities from capture fisheries resources at Bitung ...

Tabel 14. CPUE tiap alat tangkap marlin di PPS Bitung

\begin{tabular}{|c|c|c|c|c|}
\hline \multirow[b]{2}{*}{ Tahun } & \multicolumn{4}{|c|}{ Alat Tangkap } \\
\hline & Gillnet & Handline & $\begin{array}{l}\text { Purse } \\
\text { Seine }\end{array}$ & Longline \\
\hline 2012 & - & 37 & - & - \\
\hline 2013 & - & 245 & - & 4.099 \\
\hline 2014 & 10.500 & 3.564 & - & - \\
\hline 2015 & - & 241 & 383 & - \\
\hline 2016 & 900 & 556 & 1.077 & - \\
\hline 2017 & - & 372 & 4.791 & - \\
\hline 2018 & 1.005 & 436 & 483 & - \\
\hline 2019 & 600 & 786 & 1.001 & 445 \\
\hline Jumlah & 13.005 & 6.237 & 7.735 & 4.544 \\
\hline Rata-rata & 2.601 & 780 & 1.547 & 2.272 \\
\hline
\end{tabular}

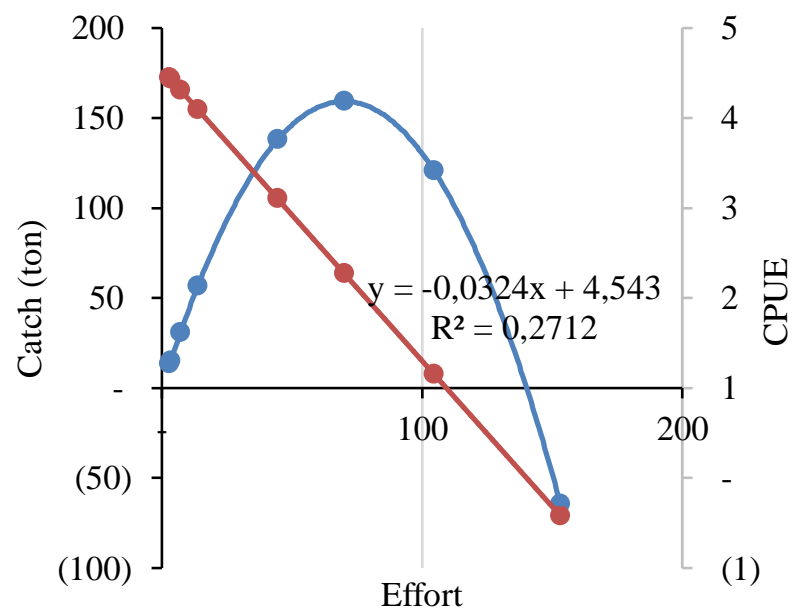

Gambar 8. Grafik nilai MSY ikan Marlin

(Gambar 8). Rerata jumlah tangkapan pada tahun 2012-2019 adalah sebesar 56 ton per tahun sehingga pemanfaatannya masih bisa diteruskan.

Tingkat Pemanfaatan marlin adalah sebesar $44 \%$ (lightly exploited) yang menyatakan stok sumber daya ikan baru tereksploitasi dalam jumlah sedikit. Pada kondisi ini, peningkatan jumlah upaya penangkapan sangat dianjurkan karena tidak mengganggu kelestarian sumber daya ikan dan CPUE masih memungkinkan meningkat.

\section{Status dan Tingkat Pemanfaatan Sumber Daya Unggulan}

Terdapat 8 jenis komoditas unggulan yang dapat dikembangkan di Kota Bitung. Pemanfaatan kedelapan jenis komoditas unggulan tersebut dapat dioptimalkan dengan melakukan pendugaan terhadap ketersediaan stok dan tingkat pemanfaatan jenis ikan unggulan.

Komoditas unggulan memiliki tingkat pemanfaatan yang beragam (Tabel 16). Tongkol, kembung, dan TMB memiliki tingkat pemanfaatan,
Tabel 15. Hasil perhitungan produksi total, standard effort, dan CPUE standar ikan marlin

\begin{tabular}{cccc}
\hline Tahun & $\begin{array}{c}\text { Produksi } \\
\text { Total } \\
(\mathrm{kg})\end{array}$ & $\begin{array}{c}\text { Standard } \\
\text { Effort } \\
\text { (trip) }\end{array}$ & $\begin{array}{c}\text { CPUE } \\
\text { Standar } \\
(\mathrm{kg} / \text { trip) }\end{array}$ \\
\hline 2012 & 110 & 3 & 37 \\
2013 & 29.330 & 7 & 4.099 \\
2014 & 35.448 & 3 & 10.500 \\
2015 & 40.040 & 105 & 383 \\
2016 & 163.653 & 153 & 1.068 \\
2017 & 66.188 & 14 & 4.791 \\
2018 & 44.683 & 44 & 1.005 \\
2019 & 72.231 & 92 & 786 \\
\hline
\end{tabular}

berturut-turut, sebesar 58\%, 61\%, dan 69\% sehingga masih memiliki peluang pengembangan yang cukup besar. Kembung merupakan komoditas perikanan yang memiliki nilai ekonomis tergolong tinggi.

Tingkat pemanfaatan ikan selar, TSK, dan layang, berturut-turut, sebesar $85 \%, 86 \%$, dan $95 \%$ (fully exploited). Hal ini berarti, stok sumber daya ikan sudah tereksploitasi mendekati nilai MSY sehingga peningkatan jumlah upaya penangkapan sangat tidak dianjurkan, walaupun hasil tangkapan masih dapat meningkat. Peningkatan upaya penangkapan akan mengganggu kelestarian sumber daya ikan dan hasil tangkapan per unit upaya pasti menurun.

Ikan marlin masih sangat memungkinkan untuk dikembangkan, karena tingkat pemanfaatan masih rendah, yaitu $44 \%$. Oleh karena itu, peluang pengembangan potensi perikanan yang masih tersisa, seperti ikan ini, hendaknya dapat dimanfaatkan dengan bijak melalui berbagai langkah dalam mewujudkan pembangunan perikanan yang berkeadilan dan berkelanjutan.

Menurut Fauzi (2002), kegiatan produksi untuk pemanfaatan sumber daya perikanan secara berkelanjutan memiliki tiga komponen, yaitu (1) komponen biologis, (2) pengelolaan sumber daya, dan (3) sosial-ekonomi perikanan. Ketiga komponen tersebut saling berkaitan satu dengan lainnya. Komponen biologis menjelaskan dinamika stok ikan; komponen pengelolaan sumber daya menjelaskan dinamika kebijakan dalam pengelolaan sumber daya perikanan, pengaturan armada penangkapan ikan (fishing effort); dan komponen sosial-ekonomi menjelaskan dinamika biaya dan keuntungan. Kalau ketiga komponen tersebut dapat terkontrol dengan baik, maka pengembangan usaha perikanan tangkap dapat dilakukan secara berkelanjutan.

Pembangunan perikanan merupakan suatu proses atau kegiatan manusia untuk meningkatkan 
Aquatic Science \& Management, Vol. 9, No. 2 (October 2021)

Tabel 16. Potensi dan tingkat pemanfaatan sumber daya ikan sebagai komoditas unggulan

\begin{tabular}{lccccc}
\hline \multicolumn{1}{c}{ Jenis ikan } & $\begin{array}{c}\text { Potensi } \\
\text { lestari } \\
\text { (ton) }\end{array}$ & $\begin{array}{c}\text { Upaya } \\
\text { Optimum } \\
\text { (trip) }\end{array}$ & $\begin{array}{c}\text { Jumah Tangkap } \\
\text { Diperbolehkan } \\
\text { (ton) }\end{array}$ & $\begin{array}{c}\text { Produksi } \\
\text { rata-rata } \\
\text { (ton) }\end{array}$ & $\begin{array}{c}\text { Tingkat } \\
\text { Pemanfaatan } \\
(\%)\end{array}$ \\
\hline Cakalang & \multicolumn{2}{c}{ penambahan upaya penangkapan masih memungkinkan untuk } \\
Tuna Sirip Kuning (TSK) & 15.251 & 1.430 & 12.201 & 10.543 & 86 \\
Layang & 7.152 & 3.453 & 5.721 & 5.416 & 95 \\
Tongkol & 10.485 & 1.425 & 8.388 & 4.893 & 58 \\
Selar & 450 & 1.003 & 360 & 306 & 85 \\
Kembung & 183 & 220 & 145 & 89 & 61 \\
Tuna Mata Besar (TMB) & 111 & 28 & 89 & 61 & 69 \\
Marlin & 159 & 70 & 127 & 56 & 44 \\
\hline
\end{tabular}

produksi di bidang perikanan dan sekaligus meningkatkan pendapatan nelayan melalui penerapan teknologi yang lebih baik (Nikijuluw, 2002). Melalui penguatan kelembagaan dan pendampingan diharapkan dapat mengangkat derajat kesejahteraan nelayan dan sekaligus menjadikan sektor perikanan tangkap sebagai leading sector dalam perekonomian di Bitung.

\section{KESIMPULAN}

Ada 8 jenis komoditas unggulan dari perikanan tangkap di PPS Bitung, yang berpeluang dikembangkan dengan potensi yang berbeda. Berikut ini kedelepan komoditas dengan potensi lestari (ton) dan tingkat pemanfaatannya (\%): 1) ikan marlin (159 ton, $44 \%)$, 2) ikan tongkol (10.485 ton, 58\%); 3) ikan kembung (183 ton, 61\%); 4) ikan tuna mata besar (TMB) (111 ton, 69\%); 5) ikan selar (450 ton, $85 \%$ ); 6) ikan tuna sirip kuning (TSK) (15.251 ton, $86 \%$ ); 7) ikan layang (7.152 ton, 95\%), dan 8) ikan cakalang.

Ucapan terima kasih. Penulis mengucapkan terima kasih kepada bpk. Sumono Darwinto, Kepala Pangkalan Pengawasan Sumber Daya Kelautan dan Perikanan Bitung, yang telah membantu dalam penyelesaian studi bagi penulis utama. "Kami menyatakan bahwa tidak ada konflik kepentingan dengan organisasi manapun mengenai bahan yang didiskusikan dalam naskah ini”.

\section{REFERENSI}

BEDWORTH, D.D. and BAILEY, J.E. (1987) Intregated Production, Control Systems: Management, Analysis, and Design. Singapore: John Wiley and Sons Inc.
DARONDO, F.A., MANOPPO, L. and LUASUNAUNG, A. (2015) Komposisi tangkapan tuna hand line di Pelabuhan Perikanan Samudera Bitung, Sulawesi Utara. Jurnal Ilmu Dan Teknologi Perikanan Tangkap, 1 (6), pp. 227232.

FAO (1995) Code of Conduct for Responsible Fisheries. Food and Agriculture Organization of the United Nations. $41 \mathrm{p}$.

FAUZI, A. (2002) Evaluasi status keberlanjutan pembangunan perikanan: aplikasi pendekatan rapfish. Jurnal Pesisir dan Lautan, 4 (3), pp. 4345.

GIRSANG, H.S. (2008) Studi Penentuan Daerah Penangkapan Ikan Tongkol melalui Pemetaan Penyebaran Klorofil-a dan Hasil Tangkapan di Pelabuhanratu, Jawa Barat. Skripsi. Bogor: IPB.

GULLAND, J.A. (1983) Fish Stock Assessment: A manual of basic method. Chicester: John Wiley and Sons.

HUSUNA, F., RANTUNG, S.V. and KOTAMBUNAN, O.O. (2017) Penilaian nelayan terhadap program pengembangan perikanan tangkap huhate di Kota Bitung Provinsi Sulawesi Utara. Akulturasi, 5 (9), pp. 667-676.

KARYANTO, K., REPPIE, E., and BUDIMAN, J. (2015) Perbandingan hasil tangkapan tuna hand line dengan teknik pengoperasian yang berbeda di Laut Maluku. Jurnal Ilmu dan Teknologi Perikanan Tangkap, 1 (6), pp. 221-226.

NAKAMURA, H. (1969) Tuna distribution and migration. London: Fishing News (Books) Ltd, 110 Fleet Street.

NIKIJULUW, V.P.H. (2002) Rezim Pengelolaan Sumberdaya Perikanan. Jakarta: PT. Pustaka Cidesindo.

PUANSALAING, D.M., BUDIMAN, J., BONEKA, F.B., MAKAPEDUA, D.M., LASUT, M.T., NGANGI, E.L.A., SUMILAT, D.A. and DARMONO, O.P. (2021) Management of scad 
Kusumaningrum et al.: Analysis of leading commodities from capture fisheries resources at Bitung ...

fisheries (Decapterus spp.) in Sulawesi Sea Waters, North Sulawesi Province, using EAFM. Aquatic Science \& Management, 9 (1), pp. 7-16.

SANTOSO, H., TUMANDUK, N., ONDANG, H. and SARANGA, R. (2017) Kajian morfometri dan molekuler ikan selar mata besar (Oci) dan ikan selar mata kecil (Tude) yang di daratkan di Pelabuhan Perikanan Samudera Bitung. Buletin Matric, 14 (1).

SIMBOLON, D., WIRYAWAN, B., WAHYUNINGRUM, P.I and WAHYUDI, H. (2011) Tingkat pemanfaatan dan pola musim penangkapan ikan lemuru di perairan Selat Bali. Buletin PSP, 19 (3), pp. 293-307.

SOEMARTO (1958) Fish behavior with special reference to pelagic shoaling species: Layang (Decapterus spp.). Proceedings of the IndoPacific Fisheries Council, 8 (3), pp. 89-93.
SOMPIE, J. (2014) Kinerja Sektor Industri Pengolahan Perikanan (SIPP) di Kota Bitung. Tesis. Salatiga: Program Doktor Universitas Kristen Satya Wacana.

TAIB, I.A.R., MANU, L. and LUASUNAUNG, A. (2018) Fluktuasi musiman cakalang (Katsuwonus pelamis): studi kasus Pelabuhan Perikanan Samudera Bitung. Jurnal Ilmu dan Teknologi Perikanan Tangkap, 3 (1), pp. 1-4.

TAMPUBOLON, S.M (1983) Ikan Tuna dan Perdagangannya. Jakarta: Gaya Baru.

WEBER, M. and DE BEAUFORT, L.F. (1931). The Fishes of the Indo-Australian Archipelago. E.J. Leiden, 6, pp. 194-201.

ZULHAM, A. (2011) Industri perikanan di Bitung. Buletin Sosek Kelautan dan Perikanan, 6 (2), pp. 53-58. 